\title{
Myelosuppressive Effect of Colaspase (L-Asparaginase) in Initial Treatment of Acute Lymphoblastic Leukaemia*
}

\author{
P. G. B. JOHNSTON, R. M. HARDISTY, H. E. M. KAY, P. G. SMITH
}

British Medical fournal, 1974, 3, 81-83

\section{Summary}

Analysis of the remission induction phase in three Medical Research Council trials of treatment of acute lymphoblastic leukaemia has provided evidence of the adverse effect of the combination of colaspase ( $L$-asparaginase) with vincristine and prednisolone. Significant myelosuppression, particularly of the granulocytic series, resulted in an increase in Gram-negative sepsis and death during the neutropenic phase induced by colaspase. The rate of blast-cell regression was increased by colaspase. It is suggested that the introduction of colaspase should be delayed until there is evidence of bone marrow regeneration in order to procure this benefit without the attendant toxicity.

\section{Introduction}

There are several drugs which can be used to obtain remission of acute lymphoblastic leukaemia (A.L.L.). Since the combination of prednisolone and vincristine is successful in $85-90 \%$ of cases (Aur et al., 1971; Medical Research Council, 1971, 1973; Holland and Glidewell, 1972) it should seldom be necessary to add another agent, but the addition of colaspase (L-asparaginase) may be valuable in hastening the onset and increasing the incidence of remission (Oettgen et al., 1970). Though complications not uncommonly result from its use (Land et al., 1970) colaspase used in short courses which do not allow sensitization to occur is relatively non-toxic.

By comparing the induction phase of treatment in three trials, only one of which included colaspase, we have assessed the benefits and hazards of combining colaspase with prednisolone and vincristine in the initial treatment of A.L.L.

\section{Patients and Methods}

The patients studied were in three consecutive trials undertaken for the Medical Research Council by its Leukaemia Committee and Working Party on Leukaemia in Childhood between January 1969 and April 1973. The three trials were Concord (January 1969 to August 1970) (Medical Research Council, 1971), UKALL I (September 1970 to December 1971) (Medical Research Council, 1973),

*Presented on behalf of the Medical Research Council Working Party on Leukaemia in Childhood.

Hospital for Sick Children, Great Ormond Street, London WC1N 3JH

P. G. B. JOHNSTON, M.B., M.R.C.P., Leukaemia Research Fellow (Present address: Plymouth General Hospital, North Friary House, Greenbank Terrace, Plymouth)

R. M. HARDISTY, F.R.C.P., F.R.C.PATH., Professor of Haematology

Royal Marsden Hospital, London SW3 6JJ

H. E. M. KAY, F.R.C.P., F.R.C.PATH., Consultant Haematologist

D.H.S.S. Cancer Epidemiology and Clinical Trials Unit, Oxford OX2 6HE

P. G. SMITH, B.sc., Research Officer and UKALL II (January 1972 to April 1973). In each trial the therapy was identical for the first six weeks apart from the addition of colaspase in the UKALL II trial. Prednisolone $40 \mathrm{mg} / \mathrm{m}^{2}$ was given daily by mouth for five weeks, tailing off during the sixth week; vincristine $1.5 \mathrm{mg} / \mathrm{m}^{2}$ was given intravenously on days 1,8 and 15; and from day 21 mercaptopurine $70 \mathrm{mg} / \mathrm{m}^{2}$ was given daily by mouth. Allopurinol, when used, was discontinued before mercaptopurine was started. In the UKALL II trial only intravenous or intramuscular colaspase $10,000 \mathrm{U} / \mathrm{m}^{2}$ was given on days 1,3 , 5 , and 8 . Treatment after the sixth week varied in many ways between the three trials.

The patients studied had all been entered into the trials at participating centres throughout the United Kingdom and Ireland and progress charts were kept on all the patients at the Leukaemia Trials Office, Royal Marsden Hospital, London. Data on the occurrence and types of infection and the results of bone marrow examinations were extracted from these records. Remission rates were obtained from the same source. Patients with incomplete data at three weeks, especially those lacking a bone marrow report, were excluded from the calculation of three-week remission rates (see table III) but were included in other analyses. In each trial several patients were withdrawn before 12 weeks had elapsed and these have been excluded.

Detailed analysis of blood neutrophil and platelet counts during the first 28 days of therapy was undertaken by examination of the hospital case notes of 27 consecutive patients from the UKALL I trial and 30 consecutive patients from the UKALL II trial treated at The Hospital for Sick Children, Great Ormond Street, London (G.O.S.), and of 22 consecutive patients from the UKALL I trial and 25 consecutive patients from the UKALL II trial treated at the Royal Marsden Hospital, Sutton (R.M.H.), Alder Hey Hospital, Liverpool (A.H.), and the Royal Hospital for Sick Children, Edinburgh (R.H.S.C.), on whom routine blood counts were performed daily or on alternative days.

Neutrophil and platelet counts were analysed in three ways: (1) absolute counts on days $0,7 \pm 1,14 \pm 1$, and $21 \pm 1$; (2) number of days from the start of treatment to the lowest recorded neutrophil and platelet counts and the absolute counts at the nadir (R.M.H., A.H., and R.H.S.C. only; this analysis could not be done on patients at G.O.S., many of whom were treated as outpatients); and (3) number of days from the start of treatment to recovery to 100,000 platelets and 1,000 and 1,500 neutrophils per $\mathrm{mm}^{3}$.

Means and confidence limits were calculated by taking the logarithms of the actual values of the individual observations and computing the means and standard errors of these transformed values. The figure shown in tables I and II are those obtained after taking antilogarithms of the values thus derived. This was done in an attempt to compensate for the skewness in the distributions of some of the observed data. Significance testing was performed on the ranked data using the Wilcoxon rank sum test.

\section{Results}

Peripheral Blood.-The mean neutrophil count was significantly lower on day 7 in the UKALL II trial than in the UKALL I trial; on day 14 the difference was less but still 
significant, while there was no significant difference on days 0 and 21 (table I). In the UKALL I trial 4.9 days elapsed before the lowest count was reached, whereas in the UKALL II trial the nadir was not reached until 8.6 days had elapsed. The mean neutrophil count at the nadir was also lower in the UKALL II trial but this was not statistically significant. There was a significant delay in recovery to 1,000 neutrophils/ $\mathrm{mm}^{3}$ in the UKALL II trial as compared with the UKALL I trial, but a somewhat faster subsequent rise from 1,000 to 1,500 neutrophils $/ \mathrm{mm}^{3}$ (table II). No significant differences were found between the platelet counts until day 14, when the mean count was significantly lower in the UKALL II trial (table I). The delay of nearly three days in recovery of platelets to $100,000 / \mathrm{mm}^{3}$ in the UKALL II trial, compared with the UKALL I trial, was similar to that of the recovery of the neutrophil count to $1,000 / \mathrm{mm}^{3}$, though the difference did not reach statistical significance (table II).

Infections.-Life-threatening infections were noticeably more common in the UKALL II trial in the first six weeks and the death rate from all causes was significantly increased $(P<0.02)$ (table III). With the exclusion of patients infected at the time of diagnosis there were similar numbers of patients with Gram-positive infections in the UKALL I and UKALL II trials but substantially more Gram-negative infections in the UKALL II trial (table IV). The time of onset of these infections was distributed throughout the six weeks and was often difficult to determine, but many occurred around the 7th to 10th days from the beginning of treatment, corresponding to the time of the minimum neutrophil count. In addition some children who were already infected at the time of diagnosis died of their infection. In the UKALL I trial only two patients died from infection within six weeks of diagnosis, compared with eight patients in the UKALL II trial, of whom seven had Gramnegative infections (including four who were infected at the time of diagnosis).

Bone Marrow (table IV).- The rate at which lymphoblasts disappeared from the bone marrow was significantly greater in the UKALL II trial than in the UKALL I and Concord trials. No systematic attempt was made to determine the precise time at which complete remission was achieved. Bone marrow aspirates were examined on day 21 and if an excess of blasts was still present a further sample was aspirated on day 42. A hypocellular marrow without excess blasts followed by the return of a normal blood count was considered sufficient evidence of complete remission. The figures for bone

TABLE IV-Serious and Life-threatening Infections with Onset during First 6 Weeks of Treatment in Two Trials. Numbers of Deaths are shown in Parentheses

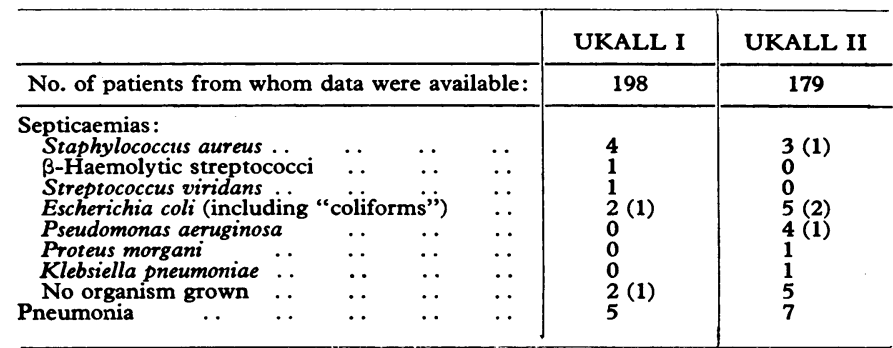

TABLE I-Neutrophil and Platelet Counts in Two Trials: Absolute Values

\begin{tabular}{|c|c|c|c|c|c|c|}
\hline & \multirow{2}{*}{ Day } & \multicolumn{2}{|c|}{ UKALL I } & \multicolumn{2}{|c|}{ UKALL II } & \multirow{2}{*}{$\mathbf{P}$} \\
\hline & & No. of Patients* & Mean Valuet & No. of Patients* & Mean Value $\dagger$ & \\
\hline Neutrophils $\left(/ \mathrm{mm}^{3}\right)\{$ & $\begin{array}{r}0 \\
7 \\
14 \\
21\end{array}$ & $\begin{array}{l}47 \\
48 \\
47 \\
46\end{array}$ & $\begin{array}{c}372(221,627) \\
364(235,564) \\
913(684,1,219) \\
2,196(1,672,2,882)\end{array}$ & $\begin{array}{l}55 \\
53 \\
53 \\
48\end{array}$ & $\begin{array}{c}454(270,762) \\
135(77,238) \\
467(289,753) \\
2,010(1,532,2,638)\end{array}$ & $\begin{array}{l}\text { N.S. } \\
<0.01 \\
<0.05 \\
\text { N.S. }\end{array}$ \\
\hline Platelets $\left(\times 10^{3} / \mathrm{mm}^{2}\right)$ & $\begin{array}{r}0 \\
7 \\
14 \\
21\end{array}$ & $\begin{array}{l}49 \\
49 \\
47 \\
47\end{array}$ & $\begin{array}{c}26(19,36) \\
30(21,42) \\
87(63,119) \\
162(129,204)\end{array}$ & $\begin{array}{l}55 \\
54 \\
52 \\
48\end{array}$ & $\begin{array}{c}28(21,37) \\
23(17,31) \\
55(40,77) \\
127(102,158)\end{array}$ & $\begin{array}{l}\text { N.S. } \\
\text { N.S. } \\
<0.05 \\
\text { N.S. }\end{array}$ \\
\hline
\end{tabular}

*Number of patients available for analysis.

tGeometric mean ( $95 \%$ confidence limits on mean). Significance tests were performed using Wilcoxon's rank sum test.

TABLE II-Minimum Values and Recovery Times for Neutrophils and Platelets in Two Trials

\begin{tabular}{|c|c|c|c|c|c|c|c|}
\hline & & & \multicolumn{2}{|c|}{ UKALL I } & \multicolumn{2}{|c|}{ UKALL II } & \multirow[b]{2}{*}{$\mathbf{P}$} \\
\hline & & & No. of Patients* & Mean Value $†$ & No. of Patients* & Mean Valuet & \\
\hline Neutrophils & $\left\{\begin{array}{l}\text { Day of lowest count } \\
\text { Minimum count } / \mathrm{mm}^{3} \\
\text { Days to recover to } 1,000 / \mathrm{mm}^{3} \\
\text { Days to recover to } 1,500 / \mathrm{mm}^{3}\end{array}\right.$ & $\begin{array}{l}\ldots \\
\therefore \\
\cdots\end{array}$ & $\begin{array}{l}22 \\
22 \\
46 \\
49\end{array}$ & $\begin{array}{l}4 \cdot 9(3 \cdot 3,7 \cdot 3) \\
91 \quad(29,287) \\
13.5(11 \cdot 4,16 \cdot 0) \\
17 \cdot 0(14 \cdot 9,19 \cdot 3)\end{array}$ & $\begin{array}{l}25 \\
25 \\
52 \\
52\end{array}$ & $\begin{array}{l}8 \cdot 6(7 \cdot 2,10 \cdot 2) \\
36 \quad(10,127) \\
17 \cdot 5(16 \cdot 3,18 \cdot 8) \\
19 \cdot 7(18 \cdot 321 \cdot 2)\end{array}$ & $\begin{array}{l}<0.01 \\
\text { N.S. } \\
<0.05 \\
\text { N.S. }\end{array}$ \\
\hline Platelets & $\left\{\begin{array}{l}\text { Day of lowest count } \mathrm{ing} \\
\text { Minimum count }\left(\times 10^{3}\right) / \mathrm{mm}^{3} \\
\text { Days to recover to } 10^{5} / \mathrm{mm}^{3} .\end{array}\right.$ & $\begin{array}{l}\ldots \\
\cdots\end{array}$ & $\begin{array}{l}22 \\
22 \\
47\end{array}$ & $\begin{array}{c}3 \cdot 0(1 \cdot 9,4 \cdot 6) \\
14.5(10 \cdot 4,20 \cdot 3) \\
13 \cdot 8(11 \cdot 7,16 \cdot 2)\end{array}$ & $\begin{array}{l}28 \\
25 \\
52\end{array}$ & $\begin{array}{c}4 \cdot 6(3 \cdot 2,6 \cdot 4) \\
14 \cdot 5(9 \cdot 1,23 \cdot 1) \\
16 \cdot 6(14 \cdot 9,18 \cdot 5)\end{array}$ & $\begin{array}{l}\text { N.S. } \\
\text { N.S. } \\
\text { N.S. }\end{array}$ \\
\hline
\end{tabular}

* Number of patients available for analysis.

tGeometric mean ( $95 \%$ confidence limits on mean). Significance tests were performed using Wilcoxon's rank sum test.

TABLE III-Progress of Patients in First 13 Weeks in Three Trials

\begin{tabular}{|c|c|c|c|c|c|c|c|c|c|c|c|}
\hline & & & & & & & & Concord & UKALL I & UKALL II & $\mathbf{P}$ \\
\hline Total Number of Patie & & & & & & & & 191 & 201 & 233 & \\
\hline $\begin{array}{cc}\text { Regression* at: } & \\
3 \text { Weeks.. } & \ldots \\
6 \text { Weeks. } & \ldots \\
13 \text { Weeks } & \ldots \\
\text { Death before } & \text { 6 weeks } \\
\text { Others } \S & . .\end{array}$ & $\begin{array}{l}\cdots \\
\because \\
\cdots\end{array}$ & $\begin{array}{l}\cdots \\
\because \\
\cdots\end{array}$ & $\begin{array}{l}\cdots \\
\cdots \\
\cdots\end{array}$ & $\begin{array}{l}\cdots \\
\because \\
\cdots\end{array}$ & $\begin{array}{l}\cdots \\
\cdots \\
\cdots\end{array}$ & $\begin{array}{l}\because \\
\because \\
\because \\
\therefore\end{array}$ & $\begin{array}{l}\cdots \\
\cdots \\
\cdots \\
\cdots\end{array}$ & $\begin{array}{r}120 / 183+(65.6 \%) \\
170(89.0 \%) \\
177(92.7 \%) \\
3(1.6 \%) \\
11(5.8 \%)\end{array}$ & $\begin{array}{r}133 / 197 \dagger(67.5 \%) \\
162(80.6 \%) \\
179(89.0 \%) \\
4(2.0 \%) \\
18(9.0 \%)\end{array}$ & $\begin{array}{r}181 / 225 \dagger(80 \cdot 4 \%) \\
208(89 \cdot 3 \%) \\
211(90 \cdot 6 \%) \\
15(6 \cdot 4 \%) \\
7(3.0 \%)\end{array}$ & $\begin{array}{l}<0.01 \\
\text { N.S. } \\
\text { N.S. } \\
<0.02\end{array}$ \\
\hline
\end{tabular}

* Regression of blast cells in bone marrow to less than $5 \%$ of cells present irrespective of cellularity (see text).
tTotal of 8 patients in Concord trial, 4 in UKALL I trial, and 8 in UKALL II trial had insufficient data for inclusion at three weeks but had complete records subsequently. Total of 8 patients in Concord

Died between 6 and 13 weeks or failed to achieve remission by 13 weeks. 
marrow recovery refer, therefore, solely to the regression of leukaemic blast cells. By three weeks only $65.6 \%$ of the patients in the Concord trial and $67.5 \%$ in the UKALL I trial but $80.4 \%$ in the UKALL II trial had less than $5 \%$ of blast cells in the marrow. A higher proportion of UKALL II marrow specimens, however, showed severely decreased cellularity at three weeks, though this finding was not sufficiently quantitative to be analysed further. At six and 13 weeks there was no significant difference between the bone marrow regression rates in the three trials.

\section{Discussion}

The validity of comparing trials not carried out simultaneously is often called into question but it seems unlikely that this caused any serious bias in this instance. In particular there was no reason to suppose that the methods of measurement and management had significantly altered within the four years under study.

Our evidence shows that the addition of colaspase during the first week of the remission induction regimen of vincristine and prednisolone causes a significantly increased suppression of both normal and leukaemic cells in the bone marrow, as shown by the increased blast-cell regression and lower blood neutrophil and platelet counts. The induced neutropenia resulted in an increased liability to serious and fatal infections to which the immunosuppressive effect of colaspase (Maral et al., 1970), the alteration of neutrophil function by asparagine depletion (Strauss et al., 1970; Skeel et al., 1971), or an effect of colaspase on the gut mucosa might also have contributed. The clinical importance of the added period of thrombocytopenia is difficult to assess, since bleeding was largely prevented by platelet transfusion.

Colaspase could cause marrow depression either directly or by potentiating the myelotoxicity of vincristine. A potentiating effect might be mediated by the liver, since the hepatotoxicity of colaspase (Land et al., 1970; Pratt and Johnson, 1971) could interfere with drug catabolism, or might directly affect the susceptibility of bone marrow cells to vincristine. Alternatively deprivation of asparagine may simply retard the proliferation rate of the regenerating haemopoietic cells. The absence of significant neurotoxicity and alopecia from vincristine in the UKALL II trial is rather against a hepatic mechanism of vincristine potentiation and favours the bone marrow as the site of action.

Notwithstanding its observed toxicity, colaspase significantly increased the rate of blast-cell regression in the UKALL II trial. It is possible that this initial reduction of leukaemic cells might lead to an increased duration of remission (Jones and Holland, 1973), but this could not be tested in these trials because of the differences in subsequent therapy. An increased death rate during remission induction, however, is not an acceptable price to pay for this theoretical advantage. It is probable that a similar long-term effect could be obtained by giving colaspase at a later phase in treatment. It is therefore recommended that colaspase should not be given during the induction phase of treatment in A.L.L. until there is evidence of marrow regeneration or until it becomes clear that other agents are failing to induce remission.

We wish to thank all the members of the M.R.C. Working Party (Chairman, Professor J. H. Hutchison) who contributed to these trials, and particularly Drs. Elizabeth Innes, Dorothy Mainwaring, and John Mantin. Miss Mollie Gilham and Miss Helen Totman gave valuable help in the collection of data.

\section{References}

Aur, R. J. A., et al. (1971). Blood, 37, 272.

Holland, J. F., and Glidewell, O. (1972). Cancer (Philadelphia), 30, 1480 Jones, B., and Holland, J. F. (1973). Blood, 42, 1015

Land, V. J., et al. (1970). Cancer (Philadelphia), 30, 339.

Maral, R., et al. (1970). Recent Results in Cancer Research, 33, 160.

Medical Research Council (1971). British Medical fournal, 4, 189.

Medical Research Council (1973). British Medical fournal, 2, 381.

Oettgen, H. F., et al. (1970). Recent Results in Cancer Research, 33, 219.

Pratt, C. B., and Johnson, W. W. (1971). Cancer (Philadelphia), 28, 361.

Skeel, R. T., Yankee, R. A., and Henderson, E. S. (1971). Fournal of Laboratory and Clinical Medicine, 77, 975.

Strauss, R. R., et al. (1970). Cancer Research, 30, 480.

\title{
Hepatitis B Antigen in Viral Hepatitis in West London
}

\author{
L. J. FARROW, S. G. LAMB, N. F. COGHILL, R. L. LINDON, JILL PREECE, \\ A. J. ZUCKERMAN, J. S. STEWART
}

British Medical fournal, 1974, 3, 83-86

\section{Summary}

During the first 12 months of a total population survey 249 patients were seen with viral hepatitis. A total of 215

West Middlesex Hospital, Isleworth, Middlesex TW7 6AF

L. J. FARROW, M.B., M.R.C.P., Senior Medical Registrar (Present address: Watford General Hospital, Watford, Herts)

N. F. COGHILL, M.B., F.R.C.P., Consultant Physician

J. S. STEWART, M.D., M.R.C.P., Consultant Physician

South Middlesex Hospital, Isleworth, Middlesex TW7 7LN

S. G. LAMB, M.B., D.P.H., Physician in Infectious Diseases and Honorary Senior Lecturer in Communicable Diseases, University College Hospita Medical School

Department of Health, London Borough of Hounslow, Hounslow, Middlesex TW3 3EL

R. L. LINDON, F.F.C.M., D.P.H., Medical Officer of Health

Department of Microbiology, London School of Hygiene and Tropical Medicine, London WC1E 7 HT

A. J. ZUCKERMAN, M.D., D.sC., Professor of Virology

JILL PREECE, Research Assistant of these were tested for hepatitis $\mathrm{B}$ antigen (HB Ag) by radioimmunoassay and $32(15 \%)$ were positive.

More than five times as many men (27) as women (5) were HBAg positive and 19 of the men were between the ages of 20 and 39 years. There were only four drug addicts among those tested, two of whom were positive, as were two of the four patients who were tattooed.

Sixty out of 86 children (under 15 years) were tested for HBAg and none was positive.

\section{Introduction}

Australia antigen, now referred to as hepatitis B antigen ( $\mathrm{HBAg}$ ) in view of its association with hepatitis $B$ infection provides a reliable serological marker of an agent which causes this type of infection (World Health Organization, 1973):

In Great Britain the reported prevalence of HBAg in patients admitted to hospital with hepatitis has varied between $4 \%$ (Ross 